\title{
GENETIC RESOURCES OF TRADITIONAL PEAR VARIETIES IN THE REGION OF SKOPJE
}

\author{
Ana Selamovska ${ }^{1}$, Elizabeta Miskoska-Milevska ${ }^{2 *}$, Olga Najdenovska ${ }^{2}$ \\ ${ }^{1}$ Department of Fruit Growing, Institute of Agriculture, SS. Cyril and Methodius University, \\ Skopje, Republic of Macedonia \\ ${ }^{2}$ Faculty of Agricultural Sciences and Food, Ss. Cyril and Methodius University, \\ Skopje, Republic of Macedonia \\ *Corresponding author, e-mail: miskoska@yahoo.com
}

\begin{abstract}
In this paper, we present the results of the phenological characteristics (flowering and ripening time), fruit characteristics (fruit mass, length, width and hardness, length of fruit stalk, number of seeds in fruit, fruit colour and taste and content of stone cells) and chemical characteristics of fruits (soluble dry matter, total sugar and total acids) of 7 traditional pear varieties (Carigradsko avche, Evropsko avche, Letna kajkushka, Karamanka, Vodenka, Zimnica and Zimska kajkushka) in the Skopje region. In the Skopje region, the analyzed pear varieties start to flower in the first decade of April. The pear variety Carigradsko avche flowered at the earliest and Zimnica at the latest. According to the ripening time, the varieties Carigradsko avche, Evropsko avche, Letna kajkushka and Karamanka are summer pear varieties, Vodenka is an autumn variety, Zimnica and Zimska kajkushka are winter varieties. The pear Zimnica had the biggest fruits. The pears Carigradsko avche, Evropsko avche, Karamanka and Vodenka had long fruit stalks. Only the variety Zimska kajkushka contains high quantity of seeds in the fruits. The highest quality fruits, juicy, with very fine to excellent taste, are met in the pears Vodenka and Karamanka. Statistically significant differences among the examined pear varieties for all fruit characteristics were found.
\end{abstract}

Key words: pear; traditional variety; fruit characteristics; Skopje region

\section{INTRODUCTION}

On the Balkan Peninsula, the pear is a fruit with long history [1-5], as well as in Macedonia as a part of this region $[6,7]$. In Macedonia, the first fossil pear fruits were found in the Ohrid and Prespa regions, and they date from the time of coastal settlements since prehistoric times. The orcharding achieved a great success in the time of St. Kliment Ohridski and St. Naum, in the $9^{\text {th }}$ and $10^{\text {th }}$ centuries. They disseminated their knowledge of fruit grafting, together with their students. In this way, they contributed to the spreading of varieties with large fruits. The Turkish dignitaries were involved in dissemination of pear varieties with sweet taste, during their travels, in the period of the Ottoman Empire. At that time, many traditional orchards were erected. Many old traditional pear cultivars such as Arapka, Ekshikuti, Ekshija, Ekserka, Zimorka, Eribasma, Karamanka, Kurtizaim, Letna kajkushka, Zimska kajkushka, Lerinka, Maslarka, Sari armut, Tiranka, Tatlija, Vodenka, Shalganka, etc., exist in the Ohrid region [6].

The orcharding was developing slowly in the period between the two world wars. The orcharding was slightly developed after the Second World War. Namely, it was at the same level as before the war period. At the beginning of the 1960's, the traditional and extensive way of fruit production was abandoned and replaced by a new system of intensive production. That period was characterized by the introduction of new pear varieties and the mass erection of new orchards. The intensive agricultural production, the introduction of new better pear varieties, the substitution of local varieties with new varieties from abroad, as well as the 
economic and social conditions, had significant negative effects on genetic diversity.

In the 1990's, the pest (Psylla pyri L.) and the bacteria (Erwinia amylowora Burr.) caused huge damages on pear production in Macedonia and also in the world. Traditional and contemporary pear production was neglected and destroyed. Today pear production becomes deficient, and there are almost no pear orchards in Macedonia. In our country, traditional pear varieties are very rare and can be found in abandoned regions and hillymountainous areas, where extensive agriculture is used. They are resistant to various abiotic and biotic factors and are also adapted to local conditions.

The traditional pear varieties represent real national wealth because of their vitality, longlasting and existence in pure nature without chemical components. Their fruits taste and smell in a specific way. Also, they have better quality characteristics and represent a significant source of starting genetic material for the selection. As a great gene fund, they are significant for the process of improving some disadvantages in the existing varieties or creation of new ones. These traditional pear varieties represent healthy organic food as they fit right into the organic agricultural production.

From the above mentioned, there is a need for studying traditional pear varieties, their determination, selection of high-quality varieties in relation to the researched characteristics, their dissemination and conservation.

\section{EXPERIMENTAL SECTION}

The aim of this study comes from necessity to know the morphological and physiological characteristics of pear varieties, as well as their behaviour towards different abiotic and biotic factors, the time of fructification, the yield etc., in selection of suitable pear varieties to soil and climatic conditions. Namely, during this study, we determined the phenological characteristics (flowering and ripening time) fruit characteristics (fruit mass $-\mathrm{g}$, fruit length $-\mathrm{cm}$, fruit width $-\mathrm{cm}$, fruit firmness $-\mathrm{g} / \mathrm{cm}^{2}$, length of fruit stalk and number of seeds in a fruit); characteristics of fruit mesocarp (colour, taste, presence of stone cells); and chemical characteristics of fruits (total sugar $-\%$, total acids $-\%$ and soluble dry matter $-\%$ ). The descriptor, developed by the International Board of Plant Genetic Resources (IBPGR) was used for determination of morphological characteristics. The fruit classification was done according to Rubcov classification [3]. According to Rubcov, small fruits have diameter of $5 \mathrm{~cm}$, medium-large fruits have diameter of $5.1-10 \mathrm{~cm}$ and large fruits have diameter of more than $10 \mathrm{~cm}$. According to the number of seeds in the fruit, pear varieties have very low quantity (0.1-1), low (1.1-3), medium (3.1-5) to high quantity of seeds (5.1-10) [8]. According to the length of the fruit stalk, pear varieties have short stalk (to $2 \mathrm{~cm}$ ), medium-long $(2.1-3.5 \mathrm{~cm})$ and long stalk (more than $3.5 \mathrm{~cm}$ ). The fruit firmness was measured with a FT02 penetrometer and the fruit mass was weighed on the Mettler analytical laboratory scale. The extraction of seeds was done manually and then the number of filled (healthy) seeds per fruit was counted. The total sugar and the soluble dry matter were measured with Carl Zeiss Jena-DDR/713457 refractometer. The total acids were determined by a standard method of titration $(\mathrm{NaOH})$. The received data were statistically processed using analysis of variance (ANOVA).

The object of this research were 7 traditional pear varieties (Carigradsko avche, Evropsko avche, Letna kajkushka, Karamanka, Vodenka, Zimnica and Zimska kajkushka) in the Skopje region.

The pear Carigradsko avche is of Turkish origin. It is characterized by tall, vigorous, branchy and luxuriant trees. Its fruit yield is early, regular and abundant (200-300 kg/tree). This variety is resistant to frost, wind and aridity. It gives the best results on deep, fertile, drained and moderate-humid soil [7].

The variety Evropsko avche is of Turkish origin. This variety forms a medium luxuriant tree with a broad-pyramidal spreading crown. It is characterized by early, regular and abundant yield. The deep, fertile, drained and moderate-humid soil gives the best results. Its usage is local, for fresh consummation, as well as for drying and processing in compote $[7,9]$.

The pear Letna kajkushka is of unknown origin. This variety is one of the widespread pear varieties in Macedonia. It is characterized by medium luxuriant trees and semi-erect branches. It is characterized by medium yield. Its fruits are small and with low quality [7].

The variety Karamanka originates from the Karaman places in Asia. It is one of the oldest pear varieties on the Balkans. This variety is present in all regions of Macedonia. It forms vigorous, branchy trees. The fruit weight causes the branches to curve down and the crown looks extraordinary. This variety is characterized by vitality, long-lasting and mediumyield trees. Its fruit yield is early. Also, it has tendency to alternate the fruit yield [3]. According to Stancević [10] the variety Karamanka is a very vigorous variety (its crown is over $40 \mathrm{~m}^{2}$ ) and a high-yield variety (148.4 kg per tree or $25000-30000 \mathrm{~kg} / \mathrm{ha}$ ). The pear 
Karamanka is a triploid variety $[3,6]$. It prefers deep, runoff and very humid soil. This variety is suitable for windy regions [7].

The pear Vodenka originates from Asia [7]. It is one of the widespread domestic pear varieties in Macedonia as well as on the Balkans. This variety has a branchy, luxuriant tree with horizontal to upright branches and a broad-pyramidal spreading crown. It is characterized as long-lasting trees. Also, this variety has a late yield. It is a high-yield variety (200-300 $\mathrm{kg} /$ tree to $2000 \mathrm{~kg} /$ tree), but fruit productivity is alternative. It stands heat and is relatively resistant to frost. The pear Vodenka can grow in windy regions [7]. Also, it is resistant to diseases [4].

The variety Zimnica is of unknown origin. It is an old domestic pear variety. This variety forms a luxuriant and branchy tree with horizontal branches. It has a sparse crown. The variety Zimnica is characterized as rather good fruitfulness variety $(150 \mathrm{~kg} /$ tree $)$.

The pear Zimska kajkushka is of unknown origin. It is assumed that this variety is a biotype with cultivar characteristics, acquired under the influence of ecological conditions. This variety is one of the widespread pear varieties in Macedonia and is present in all regions. It is characterized by a medium luxuriant tree with a dense, broad-pyramidal spreading crown. This variety is an extraordinary high-yield one, with regular yield, more than $600 \mathrm{~kg} /$ tree [6]. According to Stancević [10] and Niketić [4], the pear Zimska kajkushka has a very luxuriant tree (its crown is over $40 \mathrm{~m}^{2}$ ) and is a super high-yield variety $(178.0 \mathrm{~kg} /$ tree or more than $30000 \mathrm{~kg} / \mathrm{ha})$. It can be grown at highest altitude. Regarding the soil, this variety is not demanding [7].

The Skopje region belongs to a continentalsub-Mediterranean climate-vegetation-soil zone where the influences of sub-Mediterranean and eastcontinental climate are combined. These regions have an average year temperature in range of $11.8{ }^{\circ} \mathrm{C}-$ $13.6^{\circ} \mathrm{C}$ (average $12.7^{\circ} \mathrm{C}$ ). The sum of active temperatures under $10^{\circ} \mathrm{C}$ is in range of $3662-4293{ }^{\circ} \mathrm{C}$ (average $3942{ }^{\circ} \mathrm{C}$ ). It reduces about $500{ }^{\circ} \mathrm{C}$. Compared with the other regions, this region is characterized by the lowest rain quantity, from 460 to $583 \mathrm{~mm}$ per year (average $507 \mathrm{~mm}$ ). According to De Martonne, the average year drought index is 22.6. According to these data, the Skopje region has dry climate. The largest part of the forest in this climate region is destroyed and transformed into cultivable soil and hilly, secondary pastures. In this region one type of soil dominates (typical chromic luvisol on saprolite) [11].

This research was a part of the scientific projects Study of Autochthonous Pear Varieties in the
Republic of Macedonia (2009) and Research of Autochthonous Pear Varieties in the Republic of Macedonia (2011) which were funded by the Ministry of Agriculture, Forestry and Water Economy of Macedonia. All research analyses were performed in collaboration with professionals from the Agency for Individual Agriculture Development from Skopje.

\section{RESULTS AND DISCUSSION}

26 traditional pear cultivars exist in the Republic of Macedonia [12-14]. In the region of Skopje there are Carigradsko avche, Evropsko avche, Letna kajkushka, Karamanka, Vodenka, Zimnica and Zimska kajkushka (Figures 1-7). The researched pear varieties were found in the area of the villages Bulachani, Orlanci and Mojanci, on the foothill of the mountain Skopska Crna Gora, at altitude from 280 $\mathrm{m}$ (the village Orlanci) to $650 \mathrm{~m}$ (the village Bulachani). They are solitary and very old trees, more than 100 years old. Local inhabitants spoke about their long-lasting. These pear trees were not treated with chemicals in pest control and for protection of diseases. Also, agrotechnical or pomotechnical technology was not applied on them.

These pear trees exist without watering. Their fruits are harvested by the local inhabitants for their needs or for local markets. The relief, where these pear varieties were found, is hilly (with slope of $7^{\circ}-$ $12^{\circ}$ ), natural pasture, on the margin of a deciduous forest. The dominant soil type is terra rossa.

In some micro-regions, these pear varieties have different synonyms. The pear Carigradsko avche is also named Bela krusha because of the white color of its mesocarp (avche $=$ white). The variety Evropsko avche could be found as Akcha, Jusnibegova, Letna stambolka, Letna vodenka, Petrovka, Enisejka, Sheker armudu, etc. The pear Letna kajkushka has few synonyms as Letna kakichka, Kakichke, Poloshka. The variety Karamanka is known as Medenica, Mlechnica, Dardha tarke. The pear Vodenka is called with many names such as: Erebasma, Eribasma, Erebaska, Esenska vodenka, Vodnjanka. Also, the variety Zimska kajkushka has few synonyms as Badnikarka, Krupna poloshka, Sitna poloshka. In the Skopje region there are found two varieties Zimska kajkushka: large and small Kajkushka (Poloshka). Its name is related to the orthodox holiday Christmas Eve. The fruits of the variety Zimska kajkushka are traditional for this holiday, and they are given to little children. 


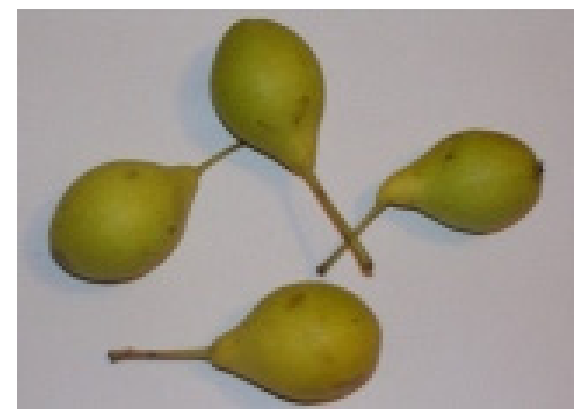

Figure 1. Pear Carigradsko avche

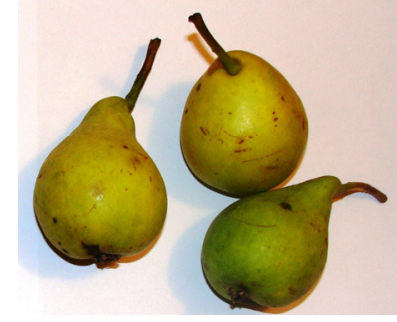

Figure 2. Pear Evropsko avche or Petrovka

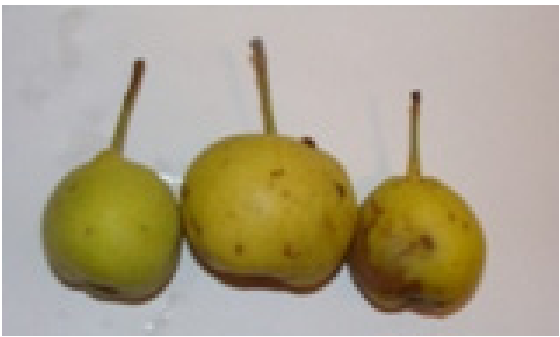

Figure 3. Pear Letna kajkushka

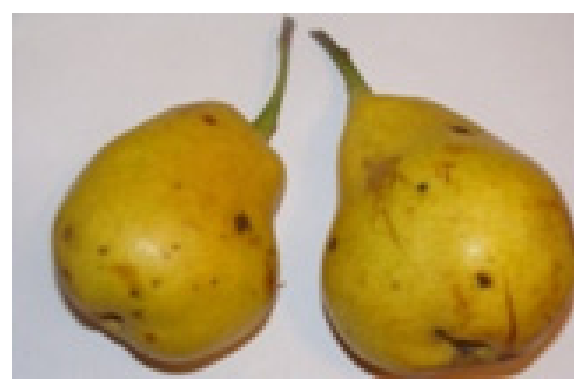

Figure 4. Pear Karamanka

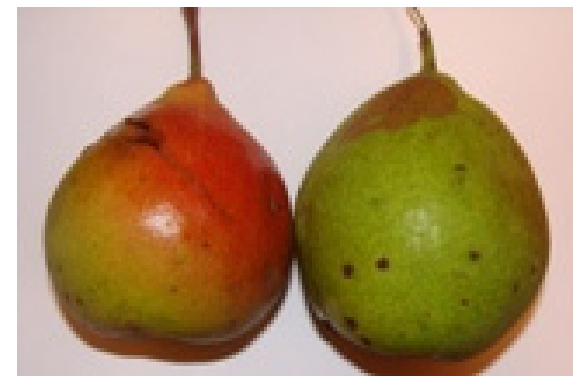

Figure 5. Pear Vodenka or Sumlija

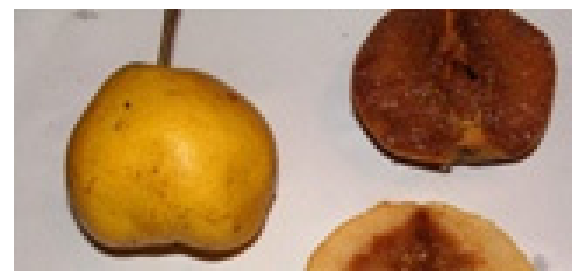

Figure 6. Pear Zimnica or Mitrovka

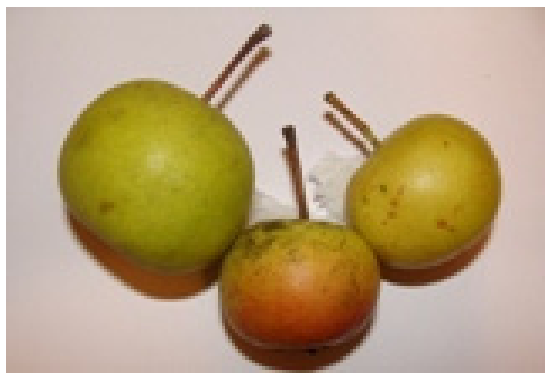

Figure 7. Pear Zimska kajkushka or Badnikarka

In the region of Skopje, the analyzed pear varieties flower in the first decade of April (April 10). The pear variety Carigradsko avche flowered at the earliest (April 8) and Zimnica flowered at the latest (April 13). The average duration (energy) of flowering of the re-searched pear varieties is 13 days. According to the flowering time, the researched pear varieties are characterized as early-flowering varieties. Depending of the climatic conditions, different varieties have different time of flowering. According to Dimitrovski [7] the variety Carigradsko avche is a late to intermediate-flowering variety, but the variety Evropsko avche is an early-intermediate flowering pear variety. The variety Karamanka is an early-flowering variety, but the pear Kajkushka is a late-flowering variety [15].

The fruits of the variety Carigradsko avche ripen at the earliest (in the first half of July, at the time of the orthodox holiday Petrovden). Next is the pear Evropsko avche (in the middle of July), than the variety Letna kajkushka (in the second decade of August), the pear Karamanka (in the third decade of August, at the time of the orthodox holiday Golema Bogorodica). At the beginning of the first half of September, the fruits of Vodenka ripen. The fruits of the pear Zimnica are collected 
at the beginning of November (around the orthodox holiday Mitrovden) and are stored until March/ April, when they are ready for consumption. Also, the fruits of Zimska kajkushka are picked in November, before the first hoarfrost. During the period of storage, the fruits become ripe and can be consumed in the winter months. Depending on the ripening time, the varieties Carigradsko avche, Evropsko avche, Letna kajkushka and Karamanka are summer pear varieties, Vodenka is an autumn variety, Zimnica and Zimska kajkushka are winter varieties [13].

If the varieties are planted at the highest altitude, their time of vegetation and flowering will be late [16]. In comparative analyses, the variety Vodenka, which is one of the widespread traditional pear varieties in Macedonia, flowers at the earliest in the Skopje region (in the first decade of April), a little later in the Resen region (in the third decade of April) and at the latest in the regions of Berovo and Pehchevo (at the beginning of May). The fruits of the variety Vodenka ripen at the earliest in the Skopje region compared with the other regions in Macedonia [14]. Compared with the other regions, the earlier time of flowering and ripening of the pear Vodenka in the Skopje region, is due to lower altitude, warmer climate and smaller quantity of rain fall during the year. However, according to the ripening time, this variety is classified as an autumn pear variety [3, 4, 7, 14].

In the region of Skopje, the largest fruits were formed by the variety Zimnica $(244.6 \mathrm{~g})$ and the smallest by the pears Letna kajkushka $(12.2 \mathrm{~g})$ and Carigradsko avche (17.8 g) (Table 1).

Table 1. Fruit characteristics of some traditional pear varieties in the Skopje region

\begin{tabular}{lccccccccc}
\hline & \multicolumn{4}{c}{ Fruit characteristics } & \multicolumn{3}{c}{ Chemical content } \\
\cline { 2 - 11 } Variety & $\begin{array}{c}\text { Fruit } \\
\text { mass } \\
(\mathrm{g})\end{array}$ & $\begin{array}{c}\text { Fruit } \\
\text { length } \\
(\mathrm{cm})\end{array}$ & $\begin{array}{c}\text { Fruit } \\
\text { width } \\
(\mathrm{cm})\end{array}$ & $\begin{array}{c}\text { Length of } \\
\text { stalk } \\
(\mathrm{cm})\end{array}$ & $\begin{array}{c}\text { Number } \\
\text { of seeds } \\
\text { in fruit }\end{array}$ & $\begin{array}{c}\text { Fruit } \\
\text { firmness } \\
\left(\mathrm{g} / \mathrm{cm}^{2}\right)\end{array}$ & $\begin{array}{c}\text { Soluble } \\
\text { dry } \\
\text { matter } \\
(\%)\end{array}$ & $\begin{array}{c}\text { Total } \\
\text { acids } \\
(\%)\end{array}$ & $\begin{array}{c}\text { Total } \\
\text { sugar } \\
(\%)\end{array}$ \\
\hline Carigradsko avche & 17.8 & 4 & 3.2 & 3.6 & 1 & 1486.3 & 14 & 0.07 & 13.7 \\
Evropsko avche & 68.9 & 7.2 & 4.9 & 3.9 & 0.3 & 1256 & 14 & 0.28 & 13.6 \\
Letna kajkushka & 12.2 & 2.6 & 2.8 & 2.1 & 4.1 & 1478 & 14.1 & 0.06 & 13.9 \\
Karamanka & 113.9 & 6.4 & 6.1 & 5 & 2.2 & 2180 & 14.5 & 0.06 & 14 \\
Vodenka & 90.3 & 6.3 & 5.4 & 3.7 & 1.7 & 1155.6 & 14.2 & 0.28 & 13 \\
Zimska kajkushka & 52.5 & 3.9 & 4.6 & 3.4 & 5.3 & 1624 & 15 & 0.27 & 14.5 \\
Zimnica & 244.6 & 6.6 & 8 & 3.2 & 3.7 & 1319 & 18.9 & 0.28 & 15.5 \\
\hline Average & 85.7 & 5.3 & 5 & 3.5 & 2.5 & 1450 & 14.9 & 0.18 & 14 \\
\hline
\end{tabular}

The varieties Evropsko avche, Vodenka and Zimska kajkushka formed medium-small fruits. The pear Karamanka gave medium-large fruits, and the variety Zimnica had large fruits. According to the Rubcov classification, the varieties Evropsko avche, Letna kajkushka and Zimska kajkushka formed small fruits. The pears Vodenka, Karamanka and Zimnica formed small fruits. According to this phenological characteristic, significant differences were found among the analyzed pear varieties (Table 2).

The fruit size is characteristic for each variety although it depends on the ecological conditions, the type of pollination, etc. [17]. The variety Carigradsko avche has very small to small fruits with average fruit mass of $36.0 \mathrm{~g}$, fruit length of 5.3 $\mathrm{cm}$ and fruit width of $4.0 \mathrm{~cm}[7,14]$. The pear Evropsko avche forms fruits with mass of $63.0 \mathrm{~g}$, fruit length of $6.0 \mathrm{~cm}$ and fruit width of $4.7 \mathrm{~cm}$ [14]. The variety Letna kajkushka is characterized by small fruits with fruit mass of $28.1 \mathrm{~g}$, fruit length of $3.2 \mathrm{~cm}$ and fruit width of $3.7 \mathrm{~cm}$ [14]. The pear
Karamanka forms medium-large to large fruits with fruit mass of $172.3 \mathrm{~g}$, fruit length of $7.8 \mathrm{~cm}$ and fruit width of $6.8 \mathrm{~cm}$. The largest fruits were detected in the regions of Resen and Kumanovo (over $250 \mathrm{~g}$ ). In dry areas, it gives smaller fruits with higher values of stone cells [14]. The pear Vodenka gives mediumsmall fruits with average fruit mass of $87.6 \mathrm{~g}$ [3], to medium-large fruits with average fruit mass of 180 $300 \mathrm{~g}[1,2,4,6,7,14]$. In dry conditions, this variety alternatively forms small fruits with poor quality and pucker taste, containing higher quantity of stone cells [7]. The fruits of the variety Zimnica have mediumlarge fruits with average fruit mass of $189.4 \mathrm{~g}$, fruit length of $6.1 \mathrm{~cm}$ and fruit width of $7.2 \mathrm{~cm}$ It gives smaller fruits and with low quality [14]. The pear Zimska kajkushka forms small-size fruits [3], with fruit mass of $45.7 \mathrm{~g}$, length of $3.7 \mathrm{~cm}$ and width of $4.5 \mathrm{~cm} \mathrm{[14].}$

As presented in Table 1, the pears Carigradsko avche, Evropsko avche, Karamanka and Vodenka had long fruit stalks. The other varieties had 
medium-long fruit stalks. The detected differences in the length of the fruit stalks among the researched pear varieties were statistically significant
(Table 3). The length of the fruit stalk is a positive characteristic of varieties growing in windy and unsuitable conditions in hilly-mountain regions [7].

Table 2. Analysis of variance (ANOVA) for fruit mass

\begin{tabular}{lcccccc}
\hline Source of variation & SS & df & MS & F & P-value & F crit \\
\hline Between groups & 1123533 & 6 & 187255.4 & 325.7 & $2.9 \mathrm{E}-101$ & 2.1 \\
Within groups & 116715 & 203 & 574.9 & & & \\
\hline Total & 1240248 & 209 & & & & \\
\hline
\end{tabular}

$\mathrm{SS}$ - sum of squares, $\mathrm{df}$ - degrees of freedom, MS - mean square, F - F-test, P-value - probability,

F-critic - critical value of $F$

Table 3. Analysis of variance (ANOVA) for length of fruit stalk

\begin{tabular}{lcccccc}
\hline Source of variation & SS & df & MS & F & P-value & F crit \\
\hline Between groups & 12921.6 & 6 & 2153.6 & 113.3 & $4.9 \mathrm{E}-62$ & 2.1 \\
Within groups & 3856.8 & 203 & 19 & & & \\
\hline Total & 16778.4 & 209 & & & & \\
\hline
\end{tabular}

$\mathrm{SS}$ - sum of squares, df - degrees of freedom, MS - mean square, F - F-test, P-value - probability, F-critic - critical value of $F$

The researched pear varieties contained low quantity of seeds in the fruit (average 2.5) (Table 4). The number of seeds in a fruit speaks about the fertility of the genotype (variety). The low quantity of seeds points to triploidy of the varieties or tendency to partenocarpy [7, 18]. The variety Zimska Kajkushka produced the highest quantity of seeds in the fruits (5.3) and the other varieties had very low to medium quantity of seeds. These differences were statistically significant (Table 4). Significant differences were found in the fruit firmness, among the researched pear varieties (Table 5).

Table 4. Analysis of variance (ANOVA) for number of seeds in fruit

\begin{tabular}{lcccccc}
\hline Source of variation & SS & df & MS & F & P-value & F crit \\
\hline Between groups & 636.2 & 6 & 106.0 & 64.4 & $2.31 \mathrm{E}-44$ & 2.1 \\
Within groups & 334.1 & 203 & 1.6 & & & \\
\hline Total & 970.3 & 209 & & & & \\
\hline
\end{tabular}

$\mathrm{SS}$ - sum of squares, $\mathrm{df}$ - degrees of freedom, MS - mean square, F - F-test, P-value - probability,

F-critic - critical value of $F$

Table 5. Analysis of variance (ANOVA) for fruit firmness

\begin{tabular}{lcccccc}
\hline Source of variation & SS & df & MS & F & P-value & F crit \\
\hline Between groups & 20679272 & 6 & 3446545 & 28.3 & $1.84 \mathrm{E}-24$ & 2.1 \\
Within groups & 24730023 & 203 & 121822.8 & & & \\
\hline Total & 45409296 & 209 & & & & \\
\hline
\end{tabular}

SS - sum of squares, $\mathrm{df}$ - degrees of freedom, MS - mean square, F - F-test, P-value - probability, F-critic - critical value of $F$

The colour of the fruit mesocarp in the researched pear varieties is whitish (Carigradsko avche), yellowish-white (Letna kajkushka, Karamanka, Zimnica and Zimska kajkushka) to yellowish (Evropsko avche and Vodenka). Very fine to excellent taste is characteristic of the pears Vodenka and Karamanka. The pear Zimska kajkushka tastes with the lowest intensity.

Very juicy mesocarp is characteristic of the pears Evropsko avche, Karamanka and Vodenka and 
the other varieties have medium-juicy mesocarp. The highest value of stone cells is found in fruits from the pear Zimnica and Zimska kajkushka. The other varieties, except Carigradsko avche, have a medium value of stone cells in the fruits. The fruits of the same varieties, planted in dry conditions and areas, contain the highest quantity of stone cells. When the fruits of the researched varieties ripen, the mesocarp rots. The average content of soluble dry matter in the fruits of the analyzed varieties was $14.9 \%$. As presented in the Table 1, the highest content of soluble dry matter was detected in the pear Zimnica (18.9\%) and the other varieties contained $14.0-15.0 \%$ soluble dry matter.

The average value of total sugar in these varieties was $14 \%$. The highest value of total sugar was measured in Karamanka, Zimnica and Zimska kajkushka, $14 \%, 15.5 \%$ and $14.5 \%$ respectively. The content of total acids was in the range of $0.06 \%$ to $0.28 \%$. The smallest amount of total acids was measured in the Carigradsko avche, Letna kajkushka and Karamanka pear varieties (Table 1). The highest sugar sweet index was characteristic of the pear Karamanka. Statistically significant differences were found in the soluble dry matter, total sugar and total acids among the researched pear varieties (Table 6, 7 and 8). According to Mratinić [3], the fruits of Vodenka contain 19.5\% soluble dry matter, $0.17 \%$ total acids and $17.9 \%$ total sugar. In the fruits of the variety Zimska kajkushka, $15.5 \%$ soluble dry matter, $0.19 \%$ total acids and $14.4 \%$ total sugar were measured [3].

Table 6. Analysis of variance (ANOVA) for soluble dry matter

\begin{tabular}{lcccccc}
\hline Source of variation & SS & df & MS & F & P-value & F crit \\
\hline Between groups & 566.9 & 6 & 94.5 & 105.4 & $1.34 \mathrm{E}-59$ & 2.1 \\
Within groups & 182 & 203 & 0.9 & & & \\
\hline Total & 748.9 & 209 & & & & \\
\hline
\end{tabular}

$\mathrm{SS}$ - sum of squares, df - degrees of freedom, MS - mean square, F - F-test, P-value - probability,

$F$-critic - critical value of $F$

Table 7. Analysis of variance for total sugar

\begin{tabular}{lcccccc}
\hline Source of variation & SS & df & MS & F & P-value & F crit \\
\hline Between groups & 112.6 & 6 & 18.8 & 320.8 & $1.1 \mathrm{E}-100$ & 2.1 \\
Within groups & 11.9 & 203 & 0.05 & & & \\
\hline Total & 124.4 & 209 & & & & \\
\hline
\end{tabular}

$\mathrm{SS}$ - sum of squares, df - degrees of freedom, MS - mean square, F - F-test, P-value - probability, F-critic - critical value of $F$

Table 8. Analysis of variance (ANOVA) for total acids

\begin{tabular}{lcccccc}
\hline Source of variation & SS & df & MS & F & P-value & F crit \\
\hline Between groups & 2.4 & 6 & 0.4 & 1427.7 & $5.1 \mathrm{E}-163$ & 2.1 \\
Within groups & 0.06 & 203 & 0.0003 & & & \\
\hline Total & 2.4 & 209 & & & & \\
\hline
\end{tabular}

$\mathrm{SS}$ - sum of squares, df - degrees of freedom, MS - mean square, F - F-test, P-value - probability, F-critic - critical value of $F$

Acknowledgement. All research analyses were performed in cooperation with professionals from the Agency of Agriculture Development in Skopje (agricultural engineer Predrag Milčovski). We express our thanks for his assistance. We would also like to express our gratitude to the Ministry of Agriculture, Forestry and Water Economy of Republic of Macedonia for their support in the completion of this project.

\section{REFERENCES}

[1] M. Milutinović, R. Miletić, R. Petrović, D. Nikolić, M. Milutinović, Variability of autochthonous pear cultivars in Timocka Krajina (Serbia), Acta Hort., 475 (1998), pp. 105-110.

[2] M. Milutinović, R. Miletić, M. Milutinović, M. Novaković, Pear Genetic Resources in West Serbia, Voćarstvo, 39 (2005), pp. 149-154. 
[3] E. Mratinić, Pear, Veselin Masleša, Belgrade, 2000. (in Serbian).

[4] M. Niketić, Fruit Variety, Pear, Cydonia and Mespilus, Zadruzna knjiga, Belgrade, 1951. (in Serbian).

[5] M. D. Stanković, D. P. Mišić, Yugoslavia an important source of fruit germplasm, Chron. Hort., 18 (1978), pp. 3-4.

[6] O. Avramovski, M. Grupčev, J. Sekulovski, Lets grafting future on old roots, GTZ, Coordinative Chamber of Prespa Park, ALLKOOP, Ohrid, 2005. (in Macedonian).

[7] T. Dimitrovski, Fruit growing, Pome fruit, Faculty of Agriculture, Skopje, 1974. (in Macedonian).

[8] J. Nyeki, M. Soltesz, The variation of seed content of fruits in pear varieties, also as function of different conditions of fertilization, as open pollination, natural autogamy and allogamy. VII International symposium on pear growing, Talca, 1998. ISHS Acta Hort., p. 475.

[9] S. Popov, T. Angelov, V. Georgievski, A. Stoyanov, Pomologia, Plovdiv, 1983. (in Bulgarian).

[10] A. Stančević, Dynamic of yield in 102 pear varieties in region of West Morava, Jugosl. voćar., 17 (1983), pp. 3-13. (in Serbian).

[11] Gj. Filipovski, R. Rizovski, P. Ristevski, The Characteristics of Climate-vegetative-soil Zones
(Regions) in The Republic of Macedonia, MASA, Skopje, 1996. (in Macedonian).

[12] A. Selamovska, K. Nikolić, Traditional pear varieties in Republic of Macedonia. Yearbook "Ecology, Health, Work and Sport", (2012), pp. 374-378. (in Serbian).

[13] A. Selamovska, Lj. Karakashova, Z. Nikolić, Winter Autochtonous Pear Varieties in Republic of Macedonia, Yearbook "Ecology, Health, Work and Sport”, (2012), pp. 379-383. (in Serbian).

[14] A. Selamovska, Traditional pear varieties in Republic of Macedonia, Monograph, Alfa 94, Skopje, 2013. (in Macedonian).

[15] I. Gjurgjević, M. Šoškić, Survey of Research of Flowering on Some Pear Cultivars in Peć. Jugosl. voćar., 3 (1968), pp. 13-21. (in Serbian).

[16] R. Jovančević, The Dynamic of Flowering in some Pear Cultivars in the Conditions of Polimlje Region, Jugosl. voćar., 14 (1980), pp. 191-198. (in Serbian).

[17] D. Vujanić-Varga, Influence of Pollinators on Mesocarpic Cell Size in Pears, Jugosl. voćar, 19 (1985), pp. 97-102. (in Serbian).

[18] J. Nyeki, M. Soltesz, J. Ivancsics, Natural tendency to parthenocarpy of pear varieties in Hungary, VII International symposium on pear growing, Talca, 1998. ISHS Acta Hort., p 475.

\title{
ГЕНЕТСКИ РЕСУРСИ НА ТРАДИЦИОНАЛНИ СОРТИ КРУШИ ВО СКОПСКИОТ РЕГИОН
}

\author{
Ана Селамовска $^{1}$, Елизабета Мискоска-Милевска ${ }^{2}$, Олга Најденовска ${ }^{2}$ \\ ${ }^{1}$ Одделение за овоштарство, Земјоделски институт, Универзитет „Св. Кирил и Методиј“, \\ Скопје, Република Македонија \\ ${ }^{2}$ Факултет за земјоделски науки и храна, Универзитет „Св. Кирил и Методиј“, \\ Скопје, Република Македонија
}

Во овој труд се прикажани резултатите од фенолошките својства (време на цутење и време на зреење), својствата на плодовите (маса на плод, должина на плод, широчина на плод, цврстина на плод, должина на дршка, број на семки во плод, боја и вкус на мезокарпот, како и содржина на каменести клетки) и хемиски својства на плодовите (вкупни суви материи, вкупни шеќери и вкупни киселини) на 7 традиционални сорти круши (цариградско авче, европско авче, летна кајкушка, караманка, воденка, зимница и зимска кајкушка), во реонот на Скопје. Во реонот на Скопје испитуваните сорти круши почнуваат да цутат во првата декада на април. Најрано цути цариградското авче, а најдоцна зимницата. Според времето на зреење на плодовите, цариградското авче, европското авче, летната кајкушка и караманката се летни сорти, воденката е есенска сорта, а зимницата и зимската кајкушка се зимски сорти. Најкрупни плодови дава сортата зимница. Долга дршка имаат цариградското авче, европското авче, караманката и воденката. Единствено сортата зимска кајкушка има високо количество на семки во плодовите. Најквалитетни плодови, сочни, со многу добар до одличен вкус имаат воденката и караманката. Утврдена е статистички значајна разлика меѓу сортите во однос на сите испитувани својства.

Клучни зборови: круша; традиционална сорта; својства на плодови; скопски регион 